Prepared for the U.S. Department of Energy under Contract DE-AC05-76RL01830

\title{
Fast Pyrolysis and Hydrotreating: 2014 State of Technology R\&D and Projections to 2017
}

SB Jones

LJ Snowden-Swan

PA Meyer

AH Zacher

MV Olarte

C Drennan

March 2015 


\title{
DISCLAIMER
}

This report was prepared as an account of work sponsored by an agency of the United States Government. Neither the United States Government nor any agency thereof, nor Battelle Memorial Institute, nor any of their employees, makes any warranty, express or implied, or assumes any legal liability or responsibility for the accuracy, completeness, or usefulness of any information, apparatus, product, or process disclosed, or represents that its use would not infringe privately owned rights. Reference herein to any specific commercial product, process, or service by trade name, trademark, manufacturer, or otherwise does not necessarily constitute or imply its endorsement, recommendation, or favoring by the United States Government or any agency thereof, or Battelle Memorial Institute. The views and opinions of authors expressed herein do not necessarily state or reflect those of the United States Government or any agency thereof.

\author{
PACIFIC NORTHWEST NATIONAL LABORATORY \\ operated by \\ BATTELLE \\ for the \\ UNITED STATES DEPARTMENT OF ENERGY \\ under Contract DE-AC05-76RL01830 \\ Printed in the United States of America \\ Available to DOE and DOE contractors from the \\ Office of Scientific and Technical Information, \\ P.O. Box 62, Oak Ridge, TN 37831-0062; \\ ph: (865) 576-8401 \\ fax: $(865) 576-5728$ \\ email: reports@adonis.osti.gov

\footnotetext{
Available to the public from the National Technical Information Service,

U.S. Department of Commerce, 5285 Port Royal Rd., Springfield, VA 22161

ph: (800) 553-6847

fax: (703) 605-6900

email: orders@ntis.fedworld.gov

online ordering: http://www.ntis.gov/ordering.htm
}

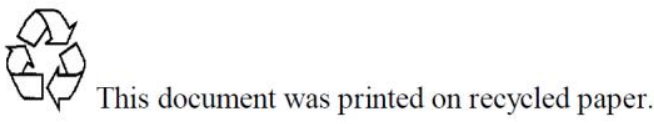




\title{
Fast Pyrolysis and Hydrotreating: 2014 State of Technology R\&D and Projections to 2017
}

\author{
SB Jones \\ LJ Snowden-Swan \\ PA Meyer \\ AH Zacher \\ MV Olarte \\ C Drennan
}

March 2015

Prepared for

the U.S. Department of Energy

under Contract DE-AC05-76RL01830

Pacific Northwest National Laboratory

Richland, Washington 99352 



\section{Contents}

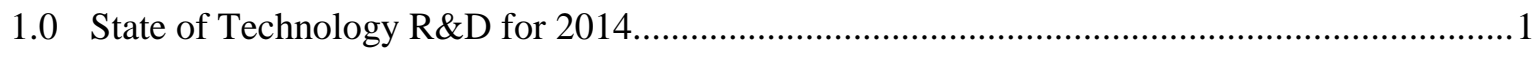

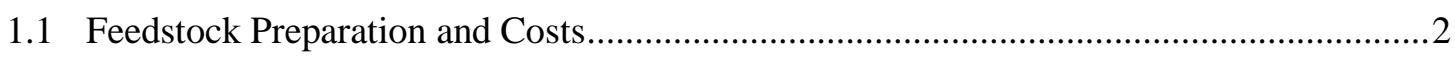

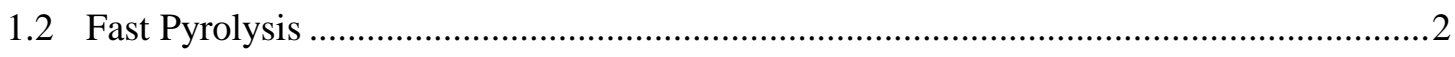

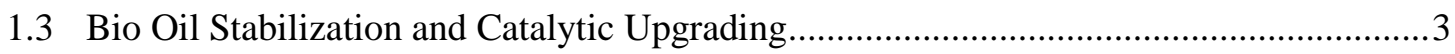

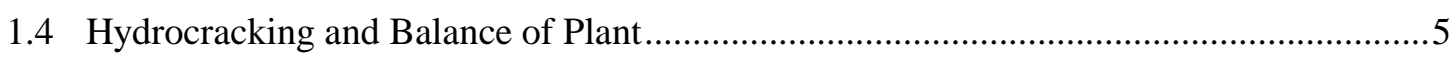

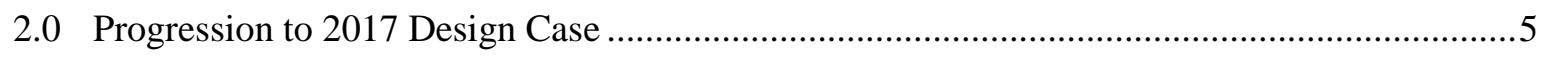

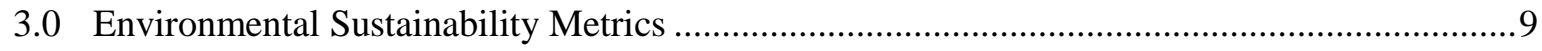

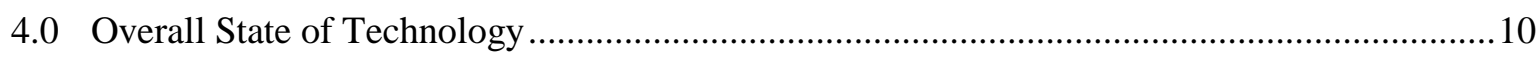

4.1 Experimental, Demonstration and Market Transformation Programs ........................... 10

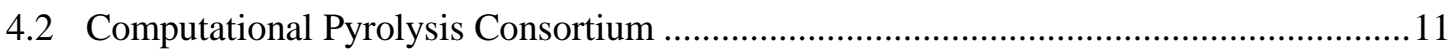

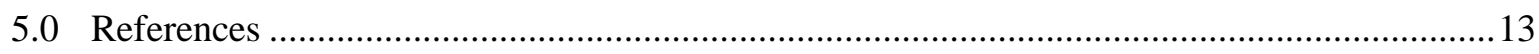

Appendix A - Methodology for GHG and Fossil Energy Calculations .......................................15

\section{Figures}

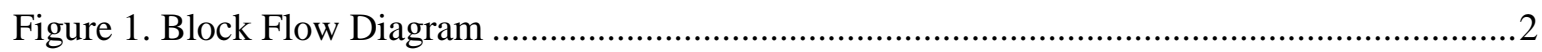

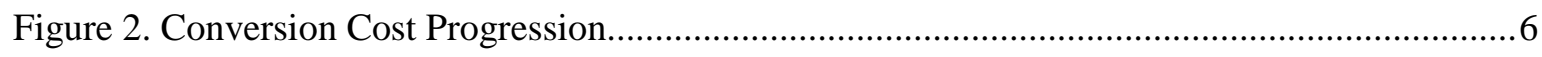

Figure 3. Computational Pyrolysis Consortium Overview ............................................................. 11

Figure 4. Plot of Experimental Plugging to Compare with Standard Gelation and Polymerization

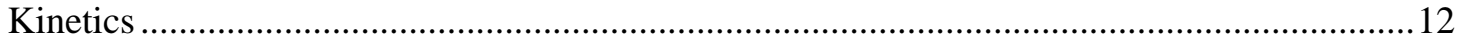

\section{Tables}

Table 1. Parameters Affecting Catalyst Related Fuel Costs ...........................................................

Table 2. Projected and SOT Reactor Operating Conditions .......................................................4

Table 3. Comparison of 2014 SOT and Projection ...................................................................

Table 4. SOT and Projections for 2009 - 2017 .......................................................................... 8

Table 5. Sustainability Metrics for Fast Pyrolysis and Upgrading Conversion ............................... 9 



\subsection{State of Technology R\&D for 2014}

The Bioenergy Technologies Office's (BETO) overarching strategic goal is "to develop commercially viable biomass utilization technologies to enable the sustainable, nationwide production of advanced biofuels that are compatible with today's transportation infrastructure and can displace a share of petroleum-derived fuels to reduce U.S. dependence on oil and encourage the creation of a new domestic bioenergy industry supporting the EISA goal of 36 bgy of renewable transportation fuels by 2022" (US DOE, 2014). As such, BETO supports research and development (R\&D) activities related to conversion of terrestrial feedstocks (e.g. wood, agricultural residues, energy crops) and algal feedstocks to liquid transportation fuels.

The Conversion R\&D technical element of the Office measures $R \& D$ progress by setting performance goals towards a future target. Modeled scenarios, in close collaboration with researchers, are used to perform conceptual evaluations termed "design cases". These provide a detailed basis for understanding the potential of conversion technologies and help identify technical barriers where research and development could lead to significant cost improvements. There are two design cases for (non-catalytic) fast pyrolysis and catalytic upgrading to hydrocarbon fuels. First is the 2009 "Production of Gasoline and Diesel from Biomass via Fast Pyrolysis, Hydrotreating and Hydrocracking: A Design Case" (Jones et al 2009). This report is based on the relatively small amount of literature available at the time, particularly for the catalytic upgrading of fast pyrolysis oil and the capital costs associated with fast pyrolysis. An updated design case, "Process Design and Economics for the Conversion of Lignocellulosic Biomass to Hydrocarbon Fuels: Fast Pyrolysis and Hydrotreating Bio-oil Pathway" (Jones et al 2013a), captures a better understanding of the capital and operating costs from BETO's research and development efforts and details the technical and economic targets expected to be achievable by 2017.

Each year, BETO assesses their research progress towards annual technical targets by incorporating data from their R\&D portfolio into technoeconomic models, from which production costs are estimated. Published data are also used, when available, to capture the current state of the art for a given technology. The state of technology (SOT) R\&D model and accompanying report reflect the minimum fuel selling price (MFSP) for the technology, modeled as an $\mathrm{n}^{\text {th }}$ plant ${ }^{1}$ obtaining a $10 \%$ internal rate of return at a net present value of zero. Economic assumptions are consistent across BETO design cases and SOTs, to allow standardization of an economic basis for technology comparisons ${ }^{2}$. This standardization does not account for differing levels of maturity amongst technologies under investigation, thus SOTs play an important role in documenting current thinking about data gaps and research needs. New projections for annual cost targets are then developed and documented as a reference for BETO's Multi-Year Program Plan $^{2}$. Finally, the SOT captures the current state of sustainability indicators, based on modeled inputs and outputs for the technology in the context of an $n^{\text {th }}$ plant design, including greenhouse gas (GHG) emissions, fossil energy consumption, total fuel yield per ton of biomass, carbon-to-fuel efficiency, water consumption, and wastewater generation.

\footnotetext{
1 “ $\mathrm{n}$ th" plant design assumptions do not account for additional first of a kind plant costs, including special financing, equipment redundancies, large contingencies and longer startup times necessary for the first few plants. For $\mathrm{n}^{\text {th }}$ plant designs, it is assumed that the costs reflect a future time when the technology is mature and several plants have already been built and are operating.

${ }^{2}$ Current and historical economic assumptions may be found in Appendix C of BETO's Multi-Year Program Plan (US DOE 2014).
} 
This State of Technology report documents the modeled costs that are based on experimental data for pyrolysis oil upgrading that was generated in FY14 and compares them to the projected costs for FY14. Previous year's assessments may be found in Jones et al (2011, 2012, 2013b).

A box flow diagram for the modeled fast pyrolysis system followed by catalytic bio oil upgrading to gasoline and diesel blendstocks is shown in Figure 1. The process comprises fast pyrolysis of biomass, three-step hydrotreating, product separation, and hydrocracking of diesel (and heavier than diesel) to increase the yield of road-transportation fuels.

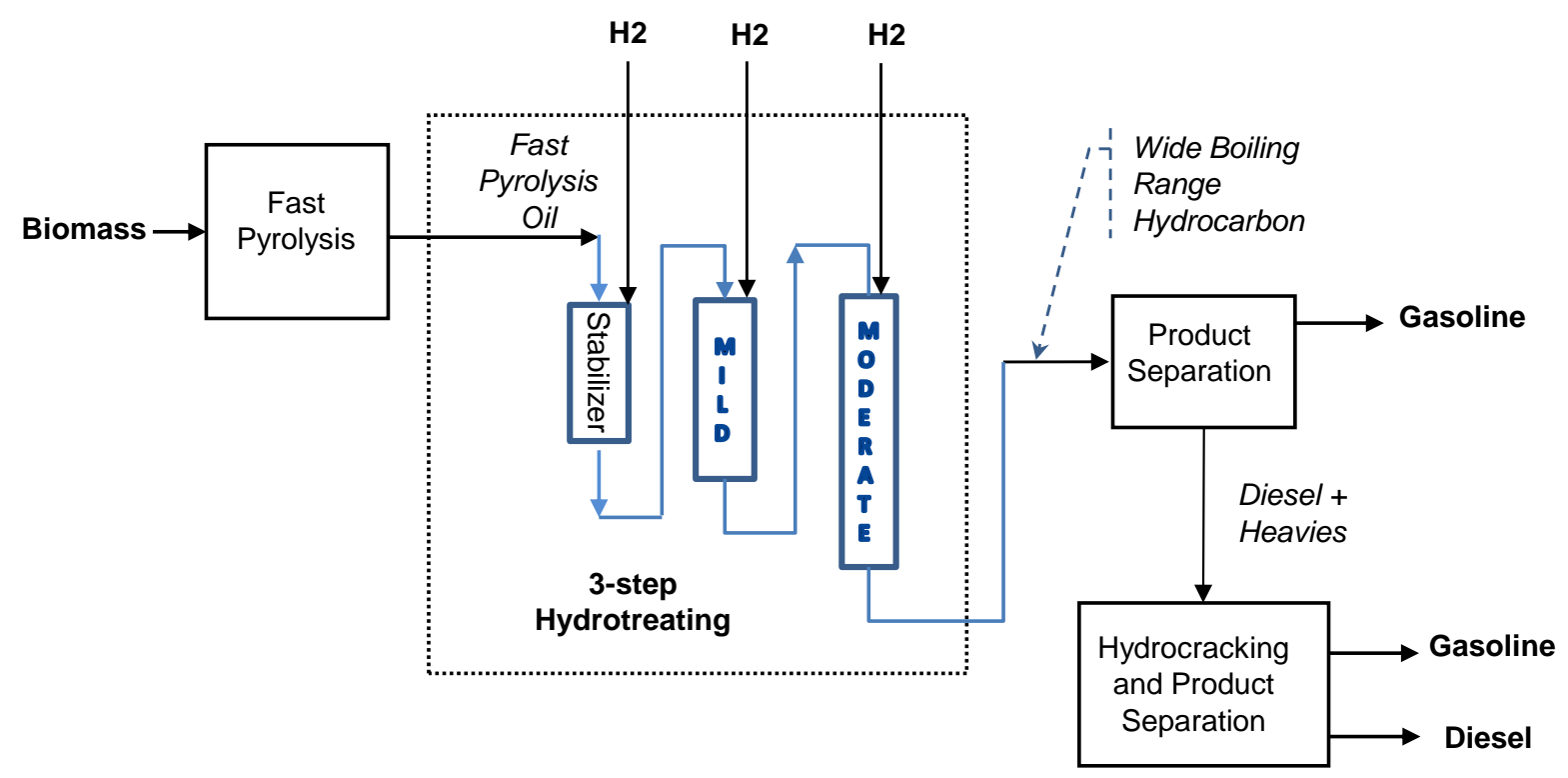

Figure 1. Block Flow Diagram

The following sections describe each processing step and it's supporting SOT data.

\subsection{Feedstock Preparation and Costs}

The Idaho National Laboratory (INL) has made significant advances in understanding feedstock preparation and its associated costs. The feedstock cost used in the 2014 SOT is based on their analysis of current feedstock costs associated with preprocessing at a depot. Biomass is dried and sized at the depot, and is delivered to the conversion plant in a form that is ready to use in a fast pyrolysis reactor. The 2014 SOT feedstock delivered cost as a dried and sized material to the conversion plant ready for use in the pyrolyzers is $\$ 101.45 /$ dry ton biomass (Cafferty 2014a). The details of the depot system and the feedstock costs are documented in the companion 2014 woody-feedstock report by Cafferty et al (2014b).

\subsection{Fast Pyrolysis}

Conventional fast pyrolysis entails rapid heating of biomass feedstock to approximately $932^{\circ} \mathrm{F}\left(500^{\circ} \mathrm{C}\right)$ in less than two seconds, at atmospheric pressure and without the addition of a catalyst. Pyrolysis vapors are rapidly quenched and captured. Cooled pyrolysis products comprise primarily liquid (water and organic compounds), char mixed with biomass ash, and non-condensable gases. Conventional fast pyrolysis technologies are already commercialized for production of food flavorings and heat/power applications. 
Thus experimental work on fast pyrolysis is not included in this SOT. Several industrial and international fast pyrolysis efforts are captured in Section 4.

The process model is based on a feed rate of 2205 dry U.S. tons per day of biomass. For the modeled costs, two 1000 metric ton per day pyrolyzers (dry feed basis) are assumed to be operating in parallel. The yield of pyrolysis oil on biomass is modeled at $62 \mathrm{wt} \%$ (dry basis). This assumed yield is based on published data for small-scale pyrolysis (1 - $20 \mathrm{~kg} / \mathrm{h}$ ) operating on low-ash pine feedstock (VTT 2012). The effects of blended feedstocks are currently being explored experimentally to inform future technoeconomic efforts.

\subsection{Bio Oil Stabilization and Catalytic Upgrading}

The use of hydrotreating to upgrade pyrolysis oil constitutes a significant portion of the fuel production costs, and is therefore the main focus of the experimental work. Hydrotreating removes oxygen, nitrogen, and sulfur and saturates olefins and some aromatics. Pyrolysis oil contains hundreds of compounds of varying degrees of reactivity. Upgrading fast pyrolysis oil to hydrocarbon oil is accomplished in three catalytic steps. Each step uses increasing severity to allow reduction of the oxygen content without causing immediate catalyst deactivation. Experimentally, and as assumed in the models, the first reactor contains a ruthenium based catalyst and operates at very mild hydrotreating conditions of $1200 \mathrm{psig}, 284$ ${ }^{\circ} \mathrm{F}\left(140{ }^{\circ} \mathrm{C}\right)$. This reduces the reactivity of certain species that cause fouling in downstream beds when the temperature is increased. The second reactor, also containing a ruthenium based catalyst, operates at 2000 psig, $485^{\circ} \mathrm{F}\left(252^{\circ} \mathrm{C}\right)$. The final bed contains a molybdenum based catalyst and operates at more severe conditions of approximately $2000 \mathrm{psig}, 750{ }^{\circ} \mathrm{F}\left(400^{\circ} \mathrm{C}\right)$, allowing near total oxygen removal.

The FY14 technical target was aimed at reducing the overall catalyst cost contribution to the modeled minimum fuel selling price (MFSP). The specific target was to meet a conversion cost (MFSP excluding the feedstock cost) of $\$ 4.09$ /gasoline gallon equivalent (gge), achieved through a $22 \%$ decrease in costs associated with the upgrading catalysis processes over the 2013 SOT catalyst related costs. Upgrading catalyst processing costs include catalyst composition, amount of catalyst required, and catalyst lifetime. Catalyst related cost reductions can be achieved through a number of means as summarized in Table 1.

Table 1. Parameters Affecting Catalyst Related Fuel Costs

\begin{tabular}{|l|l|l|}
\hline \multicolumn{1}{|c|}{ Parameter } & \multicolumn{1}{c|}{ Explanation } & \multicolumn{1}{c|}{ Cost Effect } \\
\hline $\begin{array}{l}\text { Liquid hourly space } \\
\text { velocity (LHSV), hr }\end{array}$ & $\begin{array}{l}\text { Liquid feed volume per hour } \\
\text { per volume of catalyst }\end{array}$ & $\begin{array}{l}\text { Increased LHSV reduces reactor size } \\
\text { (capital) }\end{array}$ \\
\hline $\begin{array}{l}\text { Weight hourly space } \\
\text { velocity (WHSV), } \mathrm{hr}^{-1}\end{array}$ & $\begin{array}{l}\text { Liquid feed mass per hour per } \\
\text { mass of catalyst }\end{array}$ & $\begin{array}{l}\text { Increased WHSV reduces catalyst fill } \\
\text { (operating) }\end{array}$ \\
\hline $\begin{array}{l}\text { Catalyst metals } \\
\text { loading }\end{array}$ & $\begin{array}{l}\text { Type and amount of metal on a } \\
\text { support }\end{array}$ & $\begin{array}{l}\text { Reduced loading reduces catalyst cost if } \\
\text { activity is not affected (operating) }\end{array}$ \\
\hline Catalyst support & $\begin{array}{l}\text { Many types, alumina and } \\
\text { carbon for example }\end{array}$ & $\begin{array}{l}\text { Contributes to catalyst cost and affects } \\
\text { regeneration options (operating) }\end{array}$ \\
\hline Catalyst life & $\begin{array}{l}\text { Time on stream before catalyst } \\
\text { needs complete replacement }\end{array}$ & $\begin{array}{l}\text { Longer time on stream reduces catalyst costs } \\
\text { (operating) and number of reactors (capital) }\end{array}$ \\
\hline Catalyst regeneration & $\begin{array}{l}\text { Rejuvenate catalyst through } \\
\text { treatment (for example, steam- } \\
\text { air decoking) }\end{array}$ & $\begin{array}{l}\text { Longer time before total replacement } \\
\text { (operating) }\end{array}$ \\
\hline
\end{tabular}


Experimental work supporting the 2014 SOT includes exploration of using higher WHSV, primarily in the two high-pressure reactor following stabilization, in order to potentially reduce operating costs associated with the amounts of catalyst fill required. Preliminary experimental work indicates that the quality and composition of the fuel is maintained even at higher WHSV with only a slight increase to the overall product density. This is important because the size and cost of industrial scale hydrotreating reactors are dictated by the amount of bio-oil that a catalyst can process in a given time. This throughput, often measured by WHSV represents the limit of a catalyst's ability to process bio-oil to a given target product characteristic. While increasing the WHSV can reduce catalyst related operating costs, it may also impact hydrocarbon fuel quality by not achieving sufficient oxygen removal. Operationally, increased WHSV also brings the potential for "runaway" exotherms that are detrimental to the catalyst.

The experimental test stand used to estimate the modeled costs in this analysis is a continuous flow dualtemperature zone trickle-bed reactor at approximately $400 \mathrm{~mL}$ scale. This scale is considered in the literature as bench to small pilot plant scale for trickle bed reactors (Gierman 1988) for well-understood processes. However, this term may not apply to pyrolysis oil upgrading, which is much less well known. Data collection for this SOT requires steady, continuous operation that is enabled by modifications to the reactor catalyst charge. These modifications likely facilitate more complete utilization of the catalyst bed as well as moderation of the high heat of reaction of the upgrading process. This is thought to have been a barrier to allowing higher WHSV in prior demonstrations of the technology. The experimental work used in this SOT is focused on the examining the effects of increasing the WHSV without causing process upsets or significantly impairing product quality.

The experimental study supporting this analysis covers a range of space velocities. The values used in the model represent the best achieved conditions to date that allow for significant increase in the WHSV first high-pressure bed (post stabilization) without causing a large, localized heat release (or exotherm). Exotherm issues associated with higher space velocities shown here are mitigated by using two different catalysts in the hydrocracking reactor that have different activity towards the various deoxygenation and hydrocracking reactions. The projected 2014 modeled upgrading conditions used to estimate the cost target for FY14 and the experimentally derived conditions used for SOT modeling are shown in Table 2.

Table 2. Projected and SOT Reactor Operating Conditions

\begin{tabular}{|l|l|l|l|}
\hline \multicolumn{1}{|c|}{ Reactor } & $\begin{array}{c}\text { 2013 SOT model } \\
\text { inputs derived from } \\
\text { experimental data }\end{array}$ & $\begin{array}{c}\text { 2014 Projected model } \\
\text { inputs }\end{array}$ & $\begin{array}{c}\text { 2104 SOT model inputs } \\
\text { derived from experimental } \\
\text { data }\end{array}$ \\
\hline Stabilizer & $\begin{array}{l}\text { LHSV }=0.5 \mathrm{hr}^{-1} \\
\text { WHSV }=1.41 \mathrm{hr}^{-1}\end{array}$ & $\begin{array}{l}\text { LHSV }=0.5 \mathrm{hr}^{-1} \\
\text { WHSV }=1.41 \mathrm{hr}^{-1}\end{array}$ & $\begin{array}{l}\text { LHSV }=0.5 \mathrm{hr}^{-1} \\
\text { WHSV }=1.41 \mathrm{hr}^{-1}\end{array}$ \\
\hline $1^{\text {st }}$ high pressure bed & $\begin{array}{l}\text { LHSV }=0.22 \mathrm{hr}^{-1} \\
\text { WHSV }=0.62 \mathrm{hr}^{-1}\end{array}$ & $\begin{array}{l}\text { LHSV }=0.33 \mathrm{hr}^{-1} \\
\text { WHSV }=0.93 \mathrm{hr}^{-1}\end{array}$ & $\begin{array}{l}\text { LHSV }=0.27 \mathrm{hr}^{-1} \\
\text { WHSV }=0.83 \mathrm{hr}^{-1}\end{array}$ \\
\hline $2^{\text {nd }}$ high pressure bed & $\begin{array}{l}\text { LHSV }=0.22 \mathrm{hr}^{-1} \\
\text { WHSV }=0.48 \mathrm{hr}^{-1}\end{array}$ & $\begin{array}{l}\text { LHSV }=0.22 \mathrm{hr}^{-1} \\
\text { WHSV }=0.48 \mathrm{hr}^{-1}\end{array}$ & $\begin{array}{l}\text { LHSV }=0.18 \mathrm{hr}^{-1} \\
\text { WHSV }=0.68 \mathrm{hr}^{-1}\end{array}$ \\
\hline
\end{tabular}

The key research areas for conventional fast pyrolysis oil upgrading are catalyst life and product quality. The key results contributing to the 2014 SOT are:

- Increasing the $1^{\text {st }}$ high pressure bed WHSV from $0.62 \mathrm{hr}^{-1}$ to $0.83 \mathrm{hr}^{-1}$, and the LHSV from $0.22 \mathrm{hr}-1$ to $0.27 \mathrm{hr}^{-1}$

- Increasing the $2^{\text {nd }}$ high pressure bed WHSV from $0.48 \mathrm{hr}^{-1}$ to $0.68 \mathrm{hr}^{-1}$. 
Reducing the WHSV reduced the catalyst fill, and hence the total annual catalyst replacement costs. The increased LHSV in the $1^{\text {st }}$ high pressure bed also reduced the capital cost of that reactor. Note however, that the LHSV decreased in the $2^{\text {nd }}$ high pressure reactor, thus increasing the capital costs. However, this was more than offset by the aforementioned cost reductions.

\subsection{Hydrocracking and Balance of Plant}

Hydrocracking creates smaller molecules from larger ones and saturates alkenes and aromatics. It also converts any remaining oxygenates to hydrocarbons, such as phenolic groups which appear to be the most difficult oxygenate type to remove. It is assumed in the 2014 modeled SOT costs that the diesel and heavier boiling range product are finished in a hydrocracker. This treatment cracks the heavier-thandiesel components back to the diesel range and removes residual olefins and oxygenates and saturates some of the aromatics. No data have been published in this area as of 2014, and future research is planned to address this assumption.

The main contributor to the balance of plant costs is from hydrogen generation via conventional natural gas steam reforming. It is assumed that off-gases from the fast pyrolysis reactor and from the hydrotreaters can be used in the hydrogen plant. Verification of this assumption was not conducted in 2014 in support of this SOT, and may require future work.

\subsection{Progression to 2017 Design Case}

In order to be on a trajectory toward the 2017 design case, reduced capital and operating costs associated with the upgrading catalyst are needed. These questions will be addressed in the FY15 work and beyond:

- Investigate new catalysts, evaluate regeneration and optimization methods to lengthen catalyst life,

- Develop metrics for standardized measuring and management of quality of the biomass-derived input, process intermediates and hydrocarbon products,

- Develop processes that achieve significant cost reductions, such as reactor type (e.g. ebullated bed), co-processing with petroleum in a fluidized catalytic cracking to understand options for petroleum refinery integration, catalytic pyrolysis, and partial oil recycle in the upgrading reactors,

- Process scale up for both catalytic conversion and hydrocarbon fractionation to standard fuel boiling cuts and analysis of fuel characteristics.

There are a number of ways to achieve the modeled 2017 cost goals, as described in Table 1. Figure 2 and Table 4 show the progression towards the 2017 target. Table 3 shows a comparison between the projected and the achieved 2014 results and includes a brief description for any differences. The projected conversion costs for FY15 and FY16 are:

- FY15 is $\$ 3.69 /$ gge, based on a $20 \%$ decrease in costs associated with the upgrading catalysis processes over the 2014 SOT,

- FY16 is $\$ 3.01 /$ gge, based on a $47 \%$ reduction in upgrading and finishing processing costs over the 2015 SOT. 


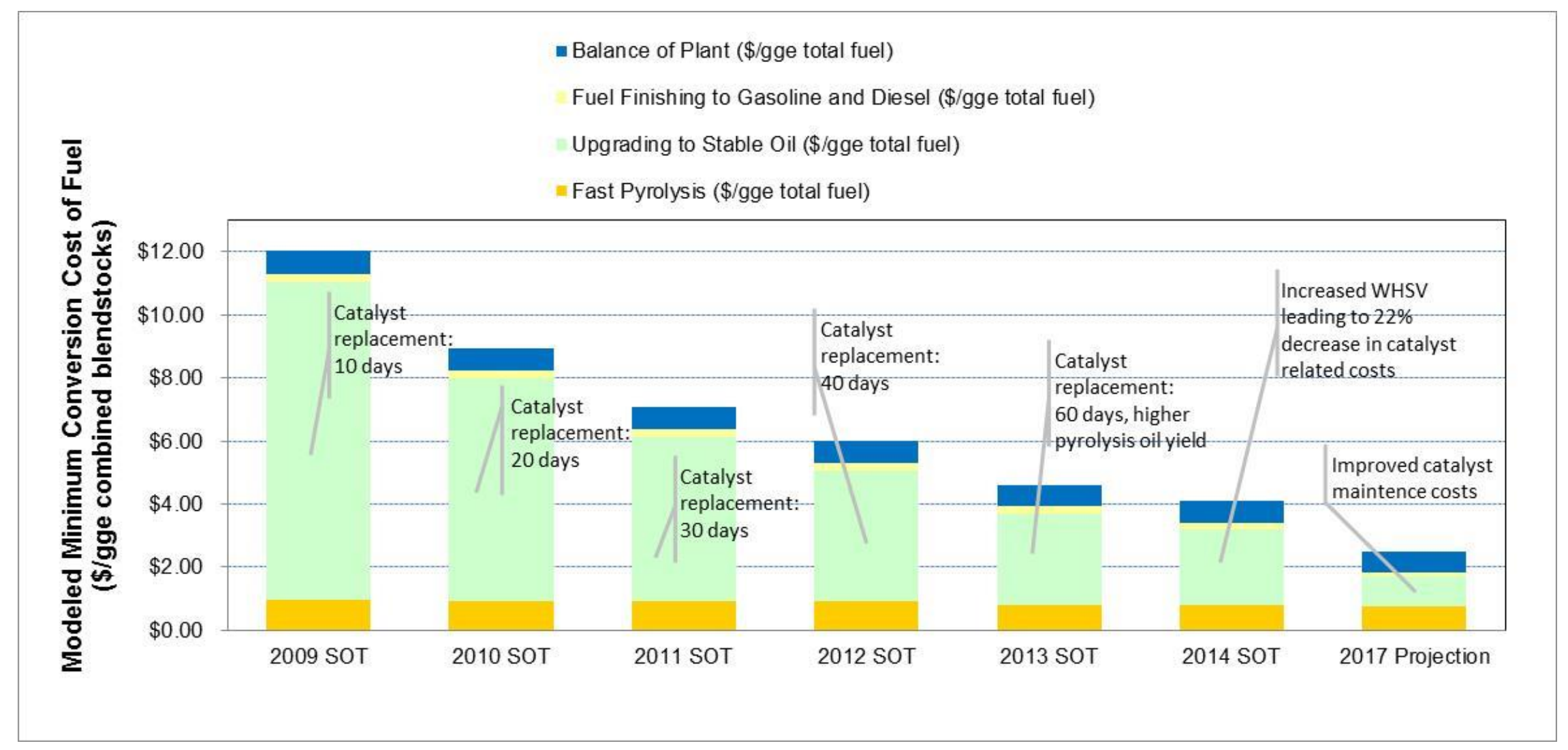

Figure 2. Conversion Cost Progression 
Table 3. Comparison of 2014 SOT and Projection

\begin{tabular}{|c|c|c|c|c|}
\hline \begin{tabular}{|l|} 
Processing Area Cost Contributions \\
$\&$ Key Technical Parameters \\
\end{tabular} & Metric & 2014 Projected & 2014 SOT & Description \\
\hline Conversion contribution & $\$$ /gal diesel blendstock & $\$ 4.46$ & $\$ 4.48$ & Observed density greater than projected \\
\hline Combined Fuel Selling Price & $\$ / G G E$ & $\$ 5.26$ & $\$ 5.26$ & \\
\hline Production Gasoline Blendstock & $\mathrm{mm}$ gallons/yr & 29 & 29 & \\
\hline Yield Combined Blendstocks & mmBTU/dry US ton & 10 & 10 & \\
\hline Natural Gas Usage & scf/dry US ton & 1,685 & 1,742 & Observed hydrogen consumption greater than projected \\
\hline \multicolumn{5}{|r|}{ t } \\
\hline Total Cost Contribution & \$/gge fuel & $\$ 1.16$ & $\$ 1.17$ & \\
\hline Capital Cost Contribution & $\$$ /gge fuel & $\$ 0.00$ & $\$ 0.00$ & \\
\hline Operating Cost Contribution & $\$$ /gge fuel & $\$ 1.16$ & $\$ 1.17$ & \\
\hline Capital Cost Contribution & $\$$ /gge fuel & $\$ 0.66$ & $\$ 0.66$ & \\
\hline Operating Cost Contribution & $\$$ /gge fuel & $\$ 0.12$ & $\$ 0.12$ & \\
\hline Pyrolysis Oil Yield (dry) & Ib organics/lb dry wood & 0.62 & 0.62 & \\
\hline \multicolumn{5}{|c|}{ Upgrading to Stable Oil via Multi-Step Hydrodeoxygenation/Hydrocracking } \\
\hline Total Cost Contribution & $\$ /$ gge fuel & $\$ 2.39$ & $\$ 2.40$ & \\
\hline Capital Cost Contribution & $\$$ /gge fuel & $\$ 0.57$ & $\$ 0.62$ & Lower than projected LHSV increased reactor size and cos \\
\hline Operating Cost Contribution & \$/gge fuel & $\$ 1.82$ & $\$ 1.78$ & \multirow{2}{*}{$\begin{array}{l}\text { Higher than projected WHSV reduced catalyst fill and cost } \\
\text { Net overall reduction in catalyst related costs }\end{array}$} \\
\hline $\begin{array}{l}\text { Annual Upgrading Catalyst Cost, } \\
\mathrm{mm} \$ / \text { year }\end{array}$ & $\begin{array}{l}\text { Annual cost is a function of: } \\
\text { WHSV, number of reactors, catalyst } \\
\text { replacement rate } \& \$ / \mathrm{lb}\end{array}$ & 100 & 97 & \\
\hline $\begin{array}{l}\text { Upgraded Oil Carbon Efficiency on } \\
\text { Pyrolysis Oil }\end{array}$ & $w t \%$ & $68 \%$ & $68 \%$ & \\
\hline Models: Case References & & $2014 \mathrm{P} 121913$ & 2014SOT HT213 & \\
\hline
\end{tabular}


Table 4. SOT and Projections for 2009 - 2017

\begin{tabular}{|c|c|c|c|c|c|c|c|c|c|c|}
\hline \begin{tabular}{|l|} 
Processing Area Cost Contributions \\
\& Key Technical Parameters \\
\end{tabular} & Metric & 2009 SOT & 2010 SOT & 2011 SOT & 2012 SOT & 2013 SOT & 2014 SOT & $\begin{array}{c}2015 \\
\text { Projected }\end{array}$ & $\begin{array}{c}2016 \\
\text { Projected }\end{array}$ & $\begin{array}{c}2017 \\
\text { Projected }\end{array}$ \\
\hline \multirow{2}{*}{ Conversion Contribution } & \$/gal gasoline blendstock & $\$ 12.40$ & $\$ 9.22$ & $\$ 7.32$ & $\$ 6.20$ & $\$ 4.51$ & $\$ 4.02$ & $\$ 3.63$ & $\$ 2.96$ & $\$ 2.44$ \\
\hline & \$/gal diesel blendstock & $\$ 13.03$ & $\$ 9.69$ & $\$ 7.69$ & $\$ 6.52$ & $\$ 5.01$ & $\$ 4.48$ & $\$ 4.03$ & $\$ 3.29$ & $\$ 2.70$ \\
\hline $\begin{array}{l}\text { Conversion Contribution, Combined } \\
\text { Blendstocks }\end{array}$ & $\$ / G G E$ & $\$ 12.02$ & $\$ 8.94$ & $\$ 7.10$ & $\$ 6.02$ & $\$ 4.60$ & $\$ 4.09$ & $\$ 3.69$ & $\$ 3.01$ & $\$ 2.47$ \\
\hline Perfomance Goal & $\$ / G G E$ & & & & & & & & & $\$ 3$ \\
\hline Combined Fuel Selling Price & $\$ / G G E$ & $\$ 13.40$ & $\$ 10.27$ & $\$ 8.26$ & $\$ 7.04$ & $\$ 5.77$ & $\$ 5.26$ & $\$ 4.75$ & $\$ 4.01$ & $\$ 3.39$ \\
\hline Production Gasoline Blendstock & $\mathrm{mm}$ gallons/yr & 30 & 30 & 30 & 30 & 29 & 29 & 29 & 29 & 29 \\
\hline Production Diesel Blendstock & $\mathrm{mm}$ gallons/yr & 23 & 23 & 23 & 23 & 32 & 32 & 32 & 32 & 32 \\
\hline Yield Combined Blendstocks & GGE/dry US ton & 78 & 78 & 78 & 78 & 87 & 87 & 87 & 87 & 87 \\
\hline Yield Combined Blendstocks & mmBTU/dry US ton & 9 & 9 & 9 & 9 & 10 & 10 & 10 & 10 & 10 \\
\hline Natural Gas Usage & scf/dry US ton & 1,115 & 1,115 & 1,115 & 1,115 & 1,685 & 1,742 & 1,685 & 1,685 & 1,685 \\
\hline \multicolumn{11}{|l|}{ Feedstock } \\
\hline Total Cost Contribution & $\$$ /gge fuel & $\$ 1.38$ & $\$ 1.33$ & $\$ 1.17$ & $\$ 1.03$ & $\$ 1.17$ & $\$ 1.17$ & $\$ 1.06$ & $\$ 0.99$ & $\$ 0.92$ \\
\hline Capital Cost Contribution & $\$$ /gge fuel & $\$ 0.00$ & $\$ 0.00$ & $\$ 0.00$ & $\$ 0.00$ & $\$ 0.00$ & $\$ 0.00$ & $\$ 0.00$ & $\$ 0.00$ & $\$ 0.00$ \\
\hline Operating Cost Contribution & $\$$ /gge fuel & $\$ 1.38$ & $\$ 1.33$ & $\$ 1.17$ & $\$ 1.03$ & $\$ 1.17$ & $\$ 1.17$ & $\$ 1.06$ & $\$ 0.99$ & $\$ 0.92$ \\
\hline Feedstock Cost & $\$ /$ dry US ton & $\$ 106.92$ & $\$ 102.96$ & $\$ 90.57$ & $\$ 79.71$ & $\$ 102.12$ & $\$ 101.45$ & $\$ 92.36$ & $\$ 86.72$ & $\$ 80.00$ \\
\hline \multicolumn{11}{|l|}{\begin{tabular}{|l} 
Fast Pyrolysis \\
\end{tabular}} \\
\hline Total Cost Contribution & $\$$ /gge fuel & $\$ 0.97$ & $\$ 0.93$ & $\$ 0.91$ & $\$ 0.90$ & $\$ 0.78$ & $\$ 0.78$ & $\$ 0.77$ & $\$ 0.76$ & $\$ 0.76$ \\
\hline Capital Cost Contribution & $\$$ /gge fuel & $\$ 0.82$ & $\$ 0.79$ & $\$ 0.76$ & $\$ 0.75$ & $\$ 0.66$ & $\$ 0.66$ & $\$ 0.65$ & $\$ 0.65$ & $\$ 0.64$ \\
\hline Operating Cost Contribution & \$/gge fuel & $\$ 0.15$ & $\$ 0.15$ & $\$ 0.15$ & $\$ 0.15$ & $\$ 0.12$ & $\$ 0.12$ & $\$ 0.12$ & $\$ 0.12$ & $\$ 0.11$ \\
\hline Pyrolysis Oil Yield (dry) & Ib organics/lb dry wood & 0.60 & 0.60 & 0.60 & 0.60 & 0.62 & 0.62 & 0.62 & 0.62 & 0.62 \\
\hline \multicolumn{11}{|c|}{ Upgrading to Stable Oil via Multi-Step Hydrodeoxygenation/Hydrocracking } \\
\hline Total Cost Contribution & $\$$ /gge fuel & $\$ 10.07$ & $\$ 7.05$ & $\$ 5.23$ & $\$ 4.17$ & $\$ 2.88$ & $\$ 2.40$ & $\$ 2.01$ & $\$ 1.35$ & $\$ 0.95$ \\
\hline Capital Cost Contribution & $\$ /$ gge fuel & $\$ 0.71$ & $\$ 0.68$ & $\$ 0.66$ & $\$ 0.65$ & $\$ 0.59$ & $\$ 0.62$ & $\$ 0.51$ & $\$ 0.45$ & $\$ 0.42$ \\
\hline Operating Cost Contribution & \$/gge fuel & $\$ 9.36$ & $\$ 6.37$ & $\$ 4.57$ & $\$ 3.52$ & $\$ 2.29$ & $\$ 1.78$ & $\$ 1.50$ & $\$ 0.90$ & $\$ 0.52$ \\
\hline $\begin{array}{l}\text { Annual Upgrading Catalyst Cost, } \\
\mathrm{mm} \$ / \text { year }\end{array}$ & \begin{tabular}{|l|} 
Annual cost is a function of: \\
WHSV $V^{2}$, number of reactors, \\
catalyst replacement rate $\& \$ / / \mathrm{b}$
\end{tabular} & 512 & 344 & 243 & 184 & 130 & 97 & 80 & 43 & 19.4 \\
\hline $\begin{array}{l}\text { Upgraded Oil Carbon Efficiency on } \\
\text { Pyrolysis Oil }\end{array}$ & wt $\%$ & $65 \%$ & $65 \%$ & $65 \%$ & $65 \%$ & $68 \%$ & $68 \%$ & $68 \%$ & $68 \%$ & $68 \%$ \\
\hline \multicolumn{11}{|c|}{ Fuel Finishing to Gasoline and Diesel via Hydrocracking and Distillation } \\
\hline Total Cost Contribution & $\$$ /gge fuel & $\$ 0.25$ & $\$ 0.24$ & $\$ 0.24$ & $\$ 0.24$ & $\$ 0.25$ & $\$ 0.24$ & $\$ 0.24$ & $\$ 0.24$ & $\$ 0.14$ \\
\hline Capital Cost Contribution & $\$$ /gge fuel & $\$ 0.16$ & $\$ 0.15$ & $\$ 0.15$ & $\$ 0.15$ & $\$ 0.16$ & $\$ 0.15$ & $\$ 0.16$ & $\$ 0.16$ & $\$ 0.07$ \\
\hline Operating Cost Contribution & $\$$ /gge fuel & $\$ 0.09$ & $\$ 0.09$ & $\$ 0.09$ & $\$ 0.09$ & $\$ 0.09$ & $\$ 0.09$ & $\$ 0.08$ & $\$ 0.08$ & $\$ 0.07$ \\
\hline \multicolumn{11}{|l|}{ Balance of Plant } \\
\hline Total Cost Contribution & $\$$ /gge fuel & $\$ 0.74$ & $\$ 0.72$ & $\$ 0.71$ & $\$ 0.71$ & $\$ 0.68$ & $\$ 0.68$ & $\$ 0.67$ & $\$ 0.66$ & $\$ 0.63$ \\
\hline Capital Cost Contribution & \$/gge fuel & $\$ 0.36$ & $\$ 0.34$ & $\$ 0.33$ & $\$ 0.33$ & $\$ 0.29$ & $\$ 0.30$ & $\$ 0.29$ & $\$ 0.29$ & $\$ 0.29$ \\
\hline Operating Cost Contribution & $\$$ /gge fuel & $\$ 0.38$ & $\$ 0.38$ & $\$ 0.38$ & $\$ 0.38$ & $\$ 0.39$ & $\$ 0.38$ & $\$ 0.38$ & $\$ 0.37$ & $\$ 0.34$ \\
\hline Models: Case References & & $\begin{array}{c}2009 \text { SOT } \\
090913\end{array}$ & $\begin{array}{c}2010 \text { SOT } \\
090913\end{array}$ & $\begin{array}{c}2012 \text { SOT } \\
090913\end{array}$ & $\begin{array}{c}2012 \text { SOT } \\
090913\end{array}$ & $\begin{array}{c}2013 \text { SOT } \\
122013\end{array}$ & $\begin{array}{c}2014 \text { SOT } \\
123014\end{array}$ & $\begin{array}{c}2015 \mathrm{P} \\
123013\end{array}$ & $\begin{array}{c}2016 \mathrm{P} \\
121913\end{array}$ & $\begin{array}{l}2017 \mathrm{P} \\
093013\end{array}$ \\
\hline
\end{tabular}




\subsection{Environmental Sustainability Metrics}

In addition to setting economic trajectories toward BETO Programmatic Goals for the conversion pathways included in the MYPP, BETO is evaluating the environmental performance of conversion pathways. The following environmental considerations are currently being assessed: greenhouse gas (GHG) emissions, fossil energy consumption, fuel yield, carbon-to-fuel efficiency, water consumption, and wastewater generation. Shown in Table 5 are the estimated metric values for the 2009, 2012, 2013 and 2014 SOT cases and the 2017 projected case for the fast pyrolysis and oil upgrading pathway. The cases shown align with the corresponding cost year scenarios presented in Table 5, the models for which are based on the 2013 design case (Jones 2013). Metrics for the 2010 and 2011 cases are not shown because they only differ from the 2009 and 2012 cases by catalyst lifetime, and therefore result in only slight changes in GHGs and fossil energy.

Table 5. Sustainability Metrics for Fast Pyrolysis and Upgrading Conversion

\begin{tabular}{|c|c|c|c|c|c|}
\hline Sustainability Metric & 2009 SOT & 2012 SOT & 2013 SOT & 2014 SOT & $\begin{array}{c}2017 \\
\text { Projected }\end{array}$ \\
\hline $\begin{array}{l}\text { Fossil Emission GHGs } \\
\left(\mathrm{g} \mathrm{CO}_{2} \text {-e/MJ fuel) }\right.\end{array}$ & 22.1 & 19.8 & 20.5 & 19.4 & 18.9 \\
\hline $\begin{array}{l}\text { Fossil Energy Consumption } \\
\text { (MJ fossil energy/MJ fuel) }\end{array}$ & 0.326 & 0.294 & 0.321 & 0.310 & 0.301 \\
\hline $\begin{array}{l}\text { Total Fuel Yield } \\
\text { (gal/dry ton wood; gge/dry ton wood) }\end{array}$ & $74 ; 78$ & $74 ; 78$ & $84 ; 87$ & $83 ; 87$ & $84 ; 87$ \\
\hline $\begin{array}{l}\text { Carbon-to-Fuel Efficiency } \\
\text { (C in fuel/C in biomass) }\end{array}$ & $38 \%$ & $38 \%$ & $47 \%$ & $47 \%$ & $47 \%$ \\
\hline $\begin{array}{l}\text { Water Consumption } \\
\left(\mathrm{m}^{3} / \text { day; gal/GGE fuel }\right.\end{array}$ & $998 ; 1.5$ & $998 ; 1.5$ & $1124 ; 1.5$ & $1088 ; 1.5$ & $1050 ; 1.4$ \\
\hline $\begin{array}{l}\text { Wastewater Generation } \\
\left(\mathrm{m}^{3} / \text { day; gal/GGE fuel }\right)\end{array}$ & $917 ; 1.4$ & $917 ; 1.4$ & $948 ; 1.3$ & $975 ; 1.3$ & $932 ; 1.3$ \\
\hline
\end{tabular}

Note: Minor changes only in 2009-2012 GHGs and Fossil Energy Consumption resulting from increased catalyst life

The metrics for GHG emissions and fossil energy consumption include both direct effects at the plant and upstream effects associated with the production and distribution of materials and energy for the plant operations, i.e., these are the life cycle emissions and energy usage for the conversion stage of the fuel supply chain. The SimaPro software (2014) is used to model and calculate cumulative GHGs and energy use for the conversion process. Mass and energy balance information from the process model, along with life cycle inventory data from the Ecoinvent (2011) and U.S. Life Cycle Inventory (2012) databases is used to populate the model. For a list of inventory data and additional assumptions, see Appendix A. Water consumption and wastewater generation values consider only direct water inputs and wastewater generation at the plant, and therefore do not include the effects of water use and discharge associated with production and distribution of energy and materials used at the plant. 


\subsection{Overall State of Technology}

\subsection{Experimental, Demonstration and Market Transformation Programs}

Upgrading catalysis remains a significant challenge. Government entities, private industry and universities are continuing research in this area. In 2014, such work includes new publications and patents regarding pyrolysis oil production and upgrading.

Several new journal articles appear since the publication of the 2013 SOT. Batch model compounds and pyrolysis oil hydrotreating are being conducted by researchers at University of Tokyo (Iino 2014), Curtin University of Technology, Perth, AU (Li 2014)), USDA (Elkasabi 2014) and Zhenzhou University, China (Xu 2013)). Semi-batch upgrading is being undertaken at NREL (French 2014) to investigate the hydrotreating effectiveness of mild hydrotreating with respect to catalyst type, hydrogen consumption and oil yield. Parapati et al, 2014, investigated single stage upgrading for five different catalysts. NREL and PNNL published a joint paper summarizing the effects of hot vapor filtration on pyrolysis oil quality and upgradability (Elliott 2014). "A review and perspective of recent bio-oil hydrotreating research" (Zacher 2014) is published in Green Chemistry, covering published research and patent literature from the past six years.

Patent applications, or receipts by industrial and academic entities, for pyrolysis-related technologies in 2014 include UOP, GTI, Phillips 66, Ensyn and Kior, as well as the University of Washington, Texas A\&M, Virginia Tech, and Aston University.

Work also continues to commercialize the production of pyrolysis oil:

- Construction on the Empyro pyrolysis oil production plant in the Netherlands is soon to be completed. The nameplate production capacity is 5.3 million gallons per year of pyrolysis oil. The oil will be used to produce electricity, steam and fuel oil from woody biomass. One aim is to develop and demonstrate a pyrolysis oil stabilization process that includes the recovery of acetic acid (Empyro 2014).

- Proton Power is developing a pyrolysis based system to produce small scale hydrogen. It can also be used to provide heat, electricity and synthetic fuels, according to their website (www.Protonpower.com). A small unit is currently powering three Caterpillar G3412 gen sets at a location in Tennessee. Claims from this installation include testing of switchgrass and components of municipal solid waste (Proton Power 2014).

- Modifications to the USDA pyrolysis system include running on recycled pyrolysis gas. Additionally, the modified system is claimed to produce bio oil with lower oxygen content and reduced acidity. Completed testing includes oak, switchgrass and pressed pennycress seeds (USDA 2104).

- Battelle Columbus, an awardee of the BETO 2010 Advanced Biofuels Technology Development solicitation is furthering development of a one ton of biomass mobile catalytic pyrolysis unit that can be used to process biomass in the field (Battelle 2013).

- Fortum, Metso, UPM, and VTT Technical Research Centre of Finland, with support of TEKES the Finnish Funding Agency for Technology and Innovation's Biorefine programme are building a first of its kind, industrial-scale combined heat and power and bio oil production facility (Fortum 2014). 
- Ensyn continues to build their 400 tpd Rapid Thermal Processing (RTPTM) units. In collaboration with UOP, they are working on refinery co-processing to produce gasoline and diesel by blending up to 5\% Renewable Fuel Oil (RFO ${ }^{\mathrm{TM}}$ ) with vacuum gas oils for FCC processing. The partnership claims testing completed in bench units, pilot units and commercial FCC units with 2015 extended commercial demonstration planned. Products are also anticipated to be "eligible under EPA's RFS2 program for the generation of D3 [co-processing] and/ or D7 [heating oil] cellulosic RINs" (Barnett 2014).

BETO's R\&D programs include efforts at national laboratories, universities, and industry. Many of these programs are focused on catalyst development that will enable a shift from petrochemical industry catalyst systems to systems designed for high-moisture, acidic environments encountered in biomass upgrading. Programs at Oak Ridge National Laboratory (ORNL) and PNNL include development of novel and robust catalysts using metal oxide supports. These catalyst systems are non-sulfided, offering the benefit of high activity at lower temperatures, but they also suffer from low tolerance to sulfur.

Efforts at DOE's Basic Energy Science Energy Frontiers Research Center (EFRC) Institute for AtomEfficient Chemical Transformation (IACT) are aimed at "armored" catalyst systems. The IACT team at Argonne National Laboratory is using atomic layer deposition to coat zeolite supports with a film of oxides, metals, or other materials to build in resistance to hydrothermal stress. Application using real bio oils is in proof of concept phase and the economics of this approach need to be better understood.

Teams at NREL, VTT, Utah State University, and elsewhere are exploring the potential for catalytic fast pyrolysis either within the fast pyrolysis vessel (in situ) or in the vapor phase prior to condensation (ex situ). A Design Case has been prepared by NREL and a State of Technology will also be published.

\subsection{Computational Pyrolysis Consortium}

BETO's Computational Pyrolysis Consortium (CPC) is in full swing after its 2013 kick-off. The consortium focuses on computational modeling across several length scales and informing processing technologies suitable for fast pyrolysis. Led by ORNL, it is supported by NREL, INL, ANL, PNNL, and the University of Delaware. Figure 3 shows the CPC technology areas and the partners assigned to each area based on core expertise and relevant experimental programs.

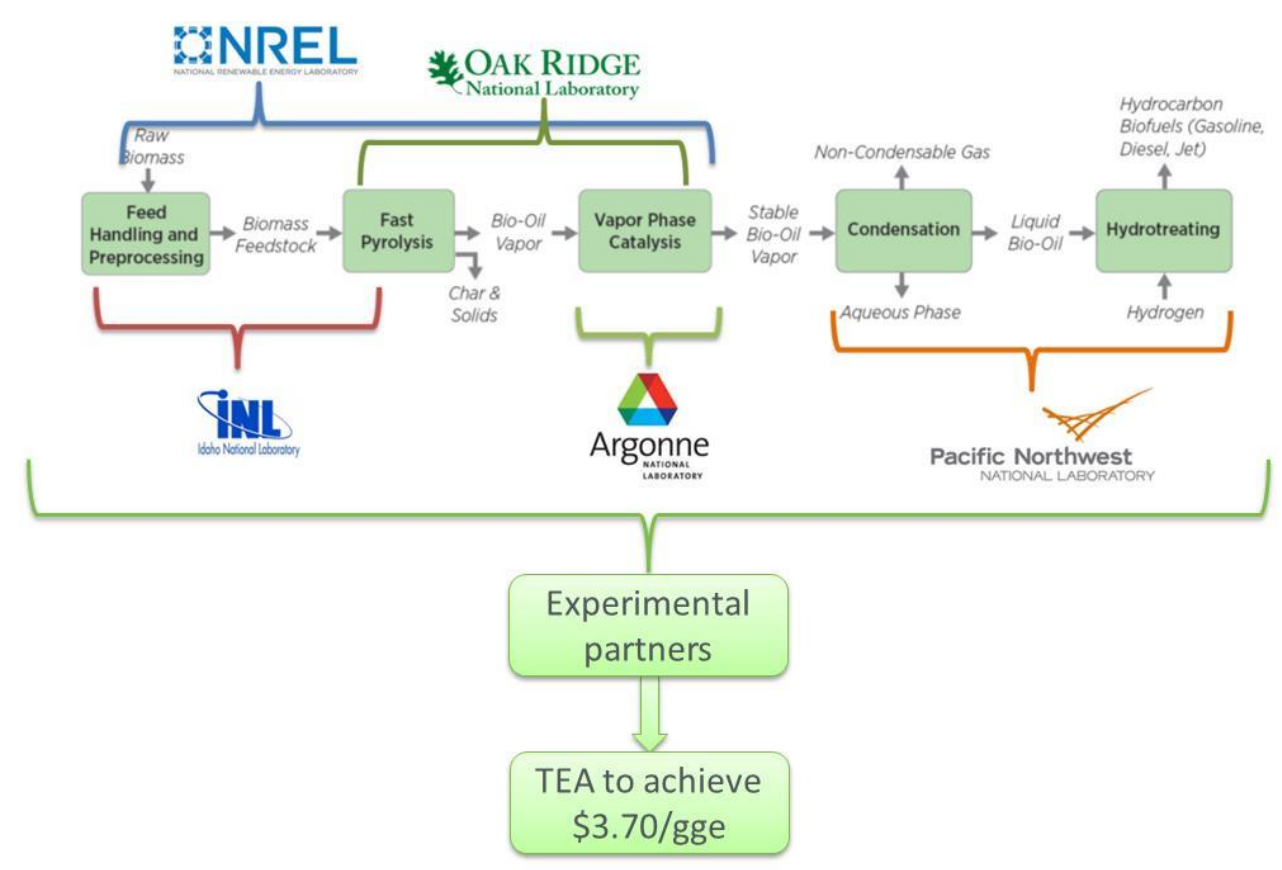

Figure 3. Computational Pyrolysis Consortium Overview 
CPC models are informed by coordinated experimental efforts and findings are used to accelerate technology advancement. Outcomes are reviewed by an Industrial Advisory Board for their insights on the findings as well as for inputs to future planning.

An example of a CPC outcome specific to the condensed phase upgrading of fast pyrolysis bio oils and its application is given here. Stabilization of molecular transition states being processed in aqueous phase leading to carbonyls may occur through polymerization and/or gelation (Yoon 2014). A plot of experimental studies and reactor plugging (shown in Figure 4) appears to be in line with gelation (rather than polymerization). Gelation is assumed to follow Stockmayer kinetics and polymerization is assumed to be $2^{\text {nd }}$ order reaction kinetics with viscosity following the Mark-Houwink-Sakurda relation and bed pressure following the Ergun equation. This finding informs design of catalyst support materials to inhibit aldol condensation (e.g., by targeting hydrophobic/hydrophilic properties not conducive to aldol condensation).

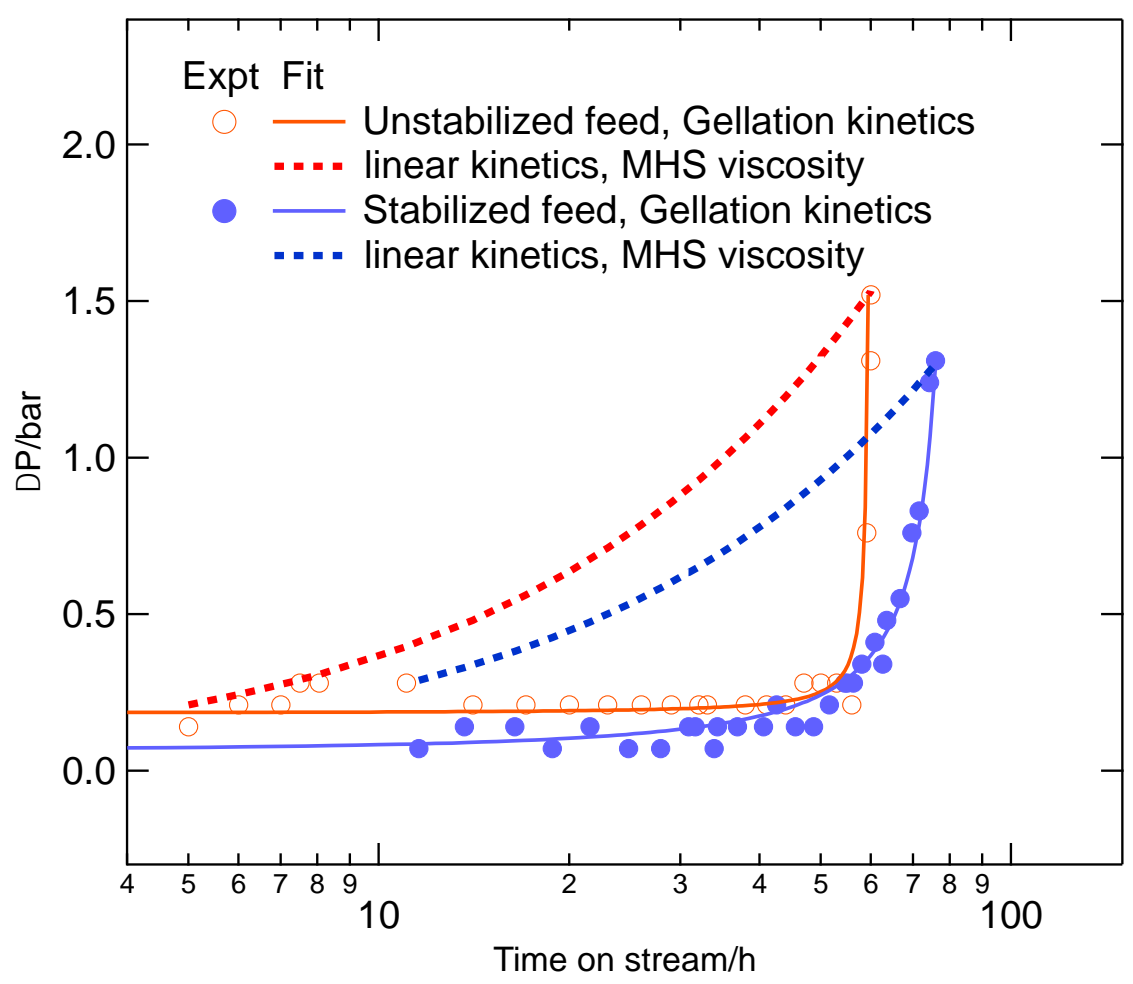

Figure 4. Plot of Experimental Plugging to Compare with Standard Gelation and Polymerization Kinetics

The CPC maintains a database that allows a technically and geographically diverse group of researchers to share and store feedstock properties, operating conditions, reaction networks, kinetic parameters, and simulation results (http://bioenergy.inl.gov). As part of the CPC outreach plan a recently established website, hosted by ORNL, contains both public and restricted access areas, allowing for both sharing of preliminary research among lab partners and public sharing of fully vetted results with the broader biomass conversion community (ORNL 2014). 


\subsection{References}

Barnett, I. 2014. Issue 36 PyNe Newsletter, IEA Bioenergy Task 34 (Dec 2014).

Battelle. 2013. (http://battelle.org/media/in-the-news/2013/11/11/the-future-of-fuel)

Cafferty, K. 2014a. Email confirmation of 2014 SOT feedstock cost to be published in the 2015 MYPP.

Cafferty, K, J Jacobson. 2014b. "Feedstock and Conversion Supply System Design and Analysis"

INL/EXT-14-33227 Idaho National Laboratory, Idaho Falls, ID.

EcoInvent Database. 2011, Version 2.2, Hamburg, Germany: Swiss Center for Life Cycle Inventories.

Elliott, D., H. Wang, R. French, S. Deutch, K. Iisa. 2014. "Hydrocarbon Liquid Production from Biomass via Hot-Vapor-Filered Fast Pyrolysis and Catalytic Hydroprocessing of the Bio-oil" Energy \& Fuels, 28:5909-5917.

Elkasabi, Y., C. Mullen, A. Pighinelli, A. Boateng. 2014. "Hydrodeoxygenation of Fast-Pyrolysis Bio-Oils from Various Feedstocks using Carbon-Supported Catalysts" Fuel Processing Technology, 123:11-18.

Empyro. 2014. http://www.biofuelsdigest.com/bdigest/2014/05/27/empyro-breaks-ground-on-biomasspyrolysis-oil-production-plant-in-the-netherlands/).

Fortum. 2014. (http://www.fortum.com/en/energy-production/fuels/bio-oil/pages/default.aspx)

French, R., J. Stunkel, S. Blank, M. Myers, M. Yung, K. Iisa. 2014. "Evaluate Impact of Catalyst Type on Oil Yield and Hydrogen Consumption form Mild Hydrotreating” Energy \& Fuels, 28:3086-3095.

Gierman, H. 1988. "Design of Laboratory Hydrotreating Reactors Scaling Down of Trickle-flow Reactors" Applied Catalysis, 43:277-286.

Iino, A., A. Cho, A. Takagaki, R. Kikuchi, S. Oyama. 2014. "Kinetic Studies of Hydrodeoxygenation of 2Methyltetrahydrofuran on a No2P/SiO2 Catalyst at Medium Pressure" Journal of Catalysis, 311:17-27.

Jones, S., C. Valkenburg, C. Walton, D. Elliott, J. Holladay, D. Stevens, C. Kinchin, S. Czernik. 2009. "Production of Gasoline and Diesel from Biomass via Fast Pyrolysis, Hydrotreating and Hydrocracking: A Design Case” PNNL-18284 Rev. 1, Pacific Northwest National Laboratory, Richland, WA.

Jones, S., J. Male. 2012. "Production of Gasoline and Diesel from Biomass via Fast Pyrolysis, Hydrotreating and Hydrocracking: 2011 State of Technology and Projections to 2017" PNNL-22133, Pacific Northwest National Laboratory, Richland, WA.

Jones S., L. Snowden-Swan. 2013a. "Production of Gasoline and Diesel from Biomass via Fast Pyrolysis, Hydrotreating and Hydrocracking: 2012 State of Technology and Projections to 2017" PNNL-22684, Pacific Northwest National Laboratory, Richland, WA.

Jones, S., P. Meyer, L. Snowden-Swan, A. Padmaperuma, E. Tan, A. Dutta, J. Jacobson, K. Cafferty. 2013b. "Process Design and Economics for the Conversion of Lignocellulosic Biomass to Hydrocarbon Fuels: Fast Pyrolysis and Hydrotreating Bio-Oil Pathway" PNNL-23053, NREL/TP-5100-61178, Pacific Northwest National Laboratory, Richland, WA.

Jones, S., L. Snowden-Swan, P. Meyer, A. Zacher, M. Olarte, C. Drennan. 2014 "Fast Pyrolysis and Hydrotreating: 2013 State of Technology R\&D and Projections to 2017" PNNL-23294, Pacific Northwest National Laboratory, Richland WA. 
Lehto, J., P. Jokela, Y. Solantausta, A. Oasmaa. 2009. "Integrated Heat, Electricity and Bio-oil Production" In: Bioenergy 2009 - Book of Proceedings, FINBIO 45:915-922. ISBN 978-952-5135-44-2

Li, X., R. Gunawan, Y. Wang, W. Chaiwat, X. Hu, M. Gholizadeh, D. Mourant, J. Bromly, C. Li. 2014. "Upgrading of Bio-Oil into Advance Biofuels and Chemicals, Part III: Changes in Aromatic Structure and Coke Forming Propensity during the Catalytic Hydrotreatment of a Fast Pyrolysis Bio-oil with $\mathrm{Pd} / \mathrm{C}$ Catalyst" Fuel, 116:642-649.

ORNL. 2014. http://energy.ornl.gov/cpc/

Parapati, D., V. Guda, V. Penmesta, P. Steele, S. Tanneru. 2014. "Single Stage Hydroprocessing of Pyrolysis Oil in a Continuous Packed-Bed Reactor" Environmental Progress \& Sustainable Energy, 33(3):726-731.

Proton Power. 2014. www.protonpower.com.

SimaPro Life Cycle Assessment Software, v. 8.0. 2014.Amersfoort, the Netherlands: Product Ecology Consultants.

USDA. 2014. (http://www.ars.usda.gov/is/pr/2014/140417.htm).

U.S. Department of Energy. November 2014. Biomass Multi-Year Program Plan. Bionergy Technologies Office, Energy Efficiency and Renewable Energy, U.S. Department of Energy, Washington D.C.

U.S. Life Cycle Inventory Database" 2012. National Renewable Energy Technology Laboratory. https://www.lcacommons.gov/nrel/search.

Xu, X., C. Zhang, Y. Liu, Y. Zhai, R. Zhang. 2013. "Two-step Catalytic Hydrodeoxygenation of Fast Pyrolysis Oil to Hydrocarbon Liquid Fuels" Chemosphese, 93:652-660.

Yoon Y., R. Rousseau, R. Weber, D. Mei, J. Lercher. 2014. "First-principles Study of Phenol Hydrogenation on Pt and Ni Catalysts in Aqueous Phase" Journal of the American Chemical Society, 136(29):10287-10298.

Zacher A., M. Olarte, D. Santosa, D. Elliott, S. Jones. 2014. “A Review and Perspective of Recent Bio-Oil Hydrotreating Research" Green Chemistry, 16(2):885-896. 


\section{Appendix A - Methodology for GHG and Fossil Energy Calculations}

The life cycle modeling software, SimaPro, is used to model the conversion stage of the fuel life cycle. Table A. 1 lists the process inventory data used in SimaPro for GHG and energy estimates for the SOT and projected cases (see Table 4). The comments column gives additional parameters such as fuel heating values and further detail on the methodology. The inventory is based on material and energy balances from the process models. Data from the Ecoinvent database (2011) and the U.S. Life Cycle Inventory Database (2012) is used for estimating energy and emissions associated with the production and distribution of materials and energy used at the plant (natural gas, electricity, catalyst, maintenance chemicals) and with waste treatment/disposal. Emissions and energy consumption for the U.S. average grid mix of electricity is assumed. The IPCC 2007 GWP 100a V1.02 inventory method and the Cumulative Energy Demand V1.07 inventory method (both included in the SimaPro package) are used to calculate the cumulative GHG emissions and fossil energy use, respectively. Due to a lack of available data on catalyst manufacture, recycling and reclamation processes, this component is approximated with a zeolite product from the Ecoinvent database. 
Table A.1. Inventory Data for Conversion GHG and Energy Estimates

\begin{tabular}{|c|c|c|c|c|c|c|c|}
\hline & & 2009 SOT & 2012 SOT & 2013 SOT & 2014 SOT & 2017 Projected & \multirow{3}{*}{ Comments } \\
\hline Products & Units & \multicolumn{5}{|c|}{ Quantity } & \\
\hline Gasoline & Btu/hr & 454500875.2 & 454500875.2 & 420538581.8 & 417937549.16 & 420214996.5 & \\
\hline Gasoline LHV & Btu/lb & 18530 & 18530 & 18940 & 18800 & 18900 & \\
\hline Diesel & Btu/hr & 373358106.2 & 373358106.2 & 509575635.5 & 507856148.5 & 509220020.0 & \\
\hline Diesel LHV & Btu/lb & 17950 & 17950 & 17880 & 17820 & 17930 & \\
\hline \multicolumn{8}{|l|}{ Resources } \\
\hline $\begin{array}{l}\text { Water, unspecified natural } \\
\text { origin } / \mathrm{kg}\end{array}$ & $\mathrm{lb} / \mathrm{hr}$ & 91668 & 91668 & 103235 & 121004 & 96410 & $\begin{array}{l}\text { Cooling makeup and boiler feedwater } \\
\text { makeup }\end{array}$ \\
\hline Air & $\mathrm{lb} / \mathrm{hr}$ & 847000 & 847000 & 789400 & 809900 & 785400 & Air for burners \\
\hline $\begin{array}{l}\text { Energy, output, from } \\
\text { gasoline }\end{array}$ & Btu/hr & 827858981.5 & 827858981.5 & 930114217.3 & 925793697.7 & 929435016.6 & Gasoline and diesel LHV together \\
\hline \multicolumn{8}{|l|}{ Materials/fuels } \\
\hline $\begin{array}{l}\text { Natural gas, high pressure, } \\
\text { at consumer/RER WITH US } \\
\text { ELECTRICITY U }\end{array}$ & Btu & 107114960 & 107114960 & 161840067 & 167343519 & 161840067 & $\begin{array}{l}\text { NG for steam reforming. Calculated NG } \\
\text { flowrate and HHV of } 23,120 \mathrm{Btu} / \mathrm{b} \text { from } \\
\text { ChemCad model }\end{array}$ \\
\hline $\begin{array}{l}\text { Electricity, medium voltage, } \\
\text { at grid/US WITH US } \\
\text { ELECTRICITY U }\end{array}$ & MWh & 11.50 & 11.50 & 10.96 & 9.25 & 9.79 & Includes power credit from steam export \\
\hline $\begin{array}{l}\text { Zeolite, powder, at } \\
\text { plant/RER WITH US } \\
\text { ELECTRICITY U }\end{array}$ & $\mathrm{lb} / \mathrm{hr}$ & 13.4 & 13.4 & 13.4 & 14.0 & 14.0 & Placeholder for stabilizer catalyst \\
\hline $\begin{array}{l}\text { Zeolite, powder, at } \\
\text { plant/RER WITH US } \\
\text { ELECTRICITY U }\end{array}$ & $\mathrm{lb} / \mathrm{hr}$ & 1645.6 & 576.0 & 400.0 & 289.4 & 54.9 & Placeholder for hydrotreating catalyst \\
\hline $\begin{array}{l}\text { Zeolite, powder, at } \\
\text { plant/RER WITH US } \\
\text { ELECTRICITY U }\end{array}$ & $\mathrm{lb} / \mathrm{hr}$ & 2.0 & 2.0 & 3.0 & 2.6 & 0.7 & Placeholder for hydrocracking catalyst \\
\hline $\begin{array}{l}\text { Zeolite, powder, at } \\
\text { plant/RER WITH US } \\
\text { ELECTRICITY U }\end{array}$ & $\mathrm{lb} / \mathrm{hr}$ & 1.7 & 1.7 & 1.8 & 1.8 & 1.8 & $\begin{array}{l}\text { Placeholder for hydrogen plant catalyst. } \\
\text { Estimates from Matros Technologies Steam } \\
\text { Reforming. catalyst life } 3 \text { yr; density } 58 \\
\text { lb/tt3, and scaling with methane flow rate }\end{array}$ \\
\hline $\begin{array}{l}\text { Hydrochloric acid, } 30 \% \text { in } \\
\text { H2O, at plant/RER WITH US } \\
\text { ELECTRICITY U }\end{array}$ & $\mathrm{lb} / \mathrm{hr}$ & 0.19 & 0.19 & 0.19 & 0.19 & 0.19 & Boiler chemicals \\
\hline $\begin{array}{l}\text { Sulphite, at plant/RER WITH } \\
\text { US ELECTRICITY U }\end{array}$ & $\mathrm{lb} / \mathrm{hr}$ & 0.19 & 0.19 & 0.19 & 0.19 & 0.19 & See above \\
\hline $\begin{array}{l}\text { Sodium hydroxide, } 50 \% \text { in } \\
\text { H2O, production mix, at } \\
\text { plant/RER WITH US } \\
\text { ELECTRICITY U }\end{array}$ & $\mathrm{lb} / \mathrm{hr}$ & 0.19 & 0.19 & 0.19 & 0.19 & 0.19 & See above \\
\hline
\end{tabular}




\begin{tabular}{|c|c|c|c|c|c|c|c|}
\hline $\begin{array}{l}\text { Chemicals inorganic, at } \\
\text { plant/GLO WITH US } \\
\text { ELECTRICITY U }\end{array}$ & $\mathrm{lb} / \mathrm{hr}$ & 0.13 & 0.13 & 0.34 & 0.34 & 0.25 & Cooling system maintenance chemicals \\
\hline $\begin{array}{l}\text { Refinery/RER/I WITH US } \\
\text { ELECTRICITY U }\end{array}$ & $\mathrm{p} / \mathrm{hr}^{1}$ & 0.0000031 & 0.0000031 & 0.0000032 & 0.0000032 & 0.0000032 & $\begin{array}{l}\text { Equipment for bio-oil refinery. Scaled based } \\
\text { on conventional refinery of } 1 \text { million tonne } \\
\text { crude oil/year. }\end{array}$ \\
\hline $\begin{array}{l}\text { Thermochemical Conversion } \\
\text { Plant }\end{array}$ & $\mathrm{p} / \mathrm{hr}^{1}$ & 0.0000063 & 0.0000063 & 0.0000063 & 0.0000063 & 0.0000063 & $\begin{array}{l}\text { Equipment for pyrolysis oil plant. Based on } \\
\text { NREL thermochem ethanol plant ( } 2000 \\
\text { MTPD) }\end{array}$ \\
\hline $\begin{array}{l}\text { Dimethyl sulfoxide, at } \\
\text { plant/RER WITH US } \\
\text { ELECTRICITY U }\end{array}$ & $\mathrm{lb} / \mathrm{hr}$ & 60 & 60 & 50 & 50 & 50 & $\begin{array}{l}\text { Dimethyl sulfoxide used as proxy for } \\
\text { dimethyl sulfide, sulfiding agent used for } \\
\text { hydrotreating catalysts. Conservative } \\
\text { estimate because more processing is } \\
\text { required than for dimethyl sulfide) }\end{array}$ \\
\hline \multicolumn{8}{|l|}{ Emissions to air } \\
\hline Carbon dioxide, fossil & $\mathrm{lb} / \mathrm{hr}$ & 12537.90 & 12537.90 & 18943.51 & 19587.60 & 18943.51 & Emissions from steam reforming of $\mathrm{NG}$ \\
\hline Carbon dioxide, biogenic & $\mathrm{lb} / \mathrm{hr}$ & 199672.09 & 199672.09 & 183158.14 & 183685.48 & 183598.68 & \\
\hline Water & $\mathrm{lb} / \mathrm{hr}$ & 124222.83 & 124222.83 & 120187.49 & 120871.98 & 119679.01 & Char burner exhausts \\
\hline Water & $\mathrm{lb} / \mathrm{hr}$ & 34027 & 34027 & 41533 & 36865 & 36940 & Evaporation and drift from cooling towers. \\
\hline Hydrogen sulfide & $\mathrm{lb} / \mathrm{hr}$ & 14.66 & 14.66 & 12.54 & 12.54 & 12.29 & \\
\hline Sulfur dioxide & $\mathrm{lb} / \mathrm{hr}$ & 100.25 & 100.25 & 100.23 & 100.23 & 100.23 & \\
\hline Carbon monoxide & $\mathrm{lb} / \mathrm{hr}$ & 0.04 & 0.04 & 0.04 & 1.76 & 0.30 & \\
\hline Methane, biogenic & $\mathrm{lb} / \mathrm{hr}$ & 2.55 & 2.55 & 2.57 & 6.31 & 2.61 & Wastewater and reformer burner exhaust \\
\hline \multicolumn{8}{|l|}{ Waste to treatment } \\
\hline $\begin{array}{l}\text { Treatment, sewage, } \\
\text { unpolluted, to wastewater } \\
\text { treatment, class } 3 / \mathrm{CH} \text { WITH } \\
\text { US ELECTRICITY U }\end{array}$ & $\mathrm{m} 3 / \mathrm{hr}$ & 38.2 & 38.2 & 39.5 & 40.6 & 38.8 & $\begin{array}{l}\text { From upgrading and blowdown. Assume } \\
\text { boiler blowdown is recycled to cooling } \\
\text { system and cooling blowdown goes to } \\
\text { WWT. }\end{array}$ \\
\hline $\begin{array}{l}\text { Disposal, wood ash mixture, } \\
\text { pure, } 0 \% \text { water, to sanitary } \\
\text { landfill/CH WITH US } \\
\text { ELECTRICITY U }\end{array}$ & $\mathrm{lb} / \mathrm{hr}$ & 1975 & 1975 & 1975 & 1975 & 1975 & Ash from fast pyrolysis \\
\hline
\end{tabular}





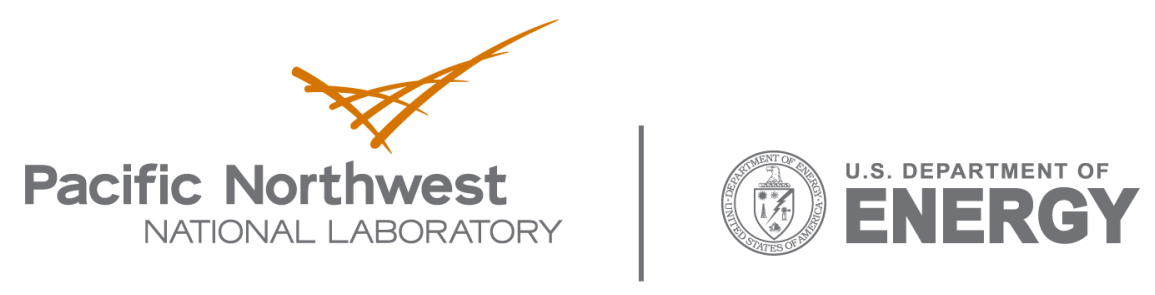

902 Battelle Boulevard

P.O. Box 999

Richland, WA 99352

1-888-375-PNNL (7665)

www.pnl.gov 